\title{
OVERVIEW
}

\section{THE LEGAL FRAMEWORK OF RELIGION-STATE RELATIONS IN SOUTHEAST ASIA}

\author{
Tahir Mahmood
}

\begin{abstract}
According to a general consensus among geographers and political scientists Southeast Asia includes eleven major countries. Though in terms of headcount Islam is the largest religion of Southeast Asia, it is the faith of the majority only in three states in the region - of the remaining eight six are dominated by the Buddhists and two by the Christians. The legal framework of religion-state relations is not uniform either in Southeast Asia as a whole or within any of these three religion-based groups of countries. The wide diversity of religion-state relations in Southeast Asia is indeed fascinating.
\end{abstract}

\section{Introduction}

The interaction of law and religion in the Asian continent is one of my major areas of study. In recent years, I have been involved in academic partnership in this field with the International Center for Law and Religion Studies at America's Brigham Young University and have been in the company of its distinguished director, Professor Cole Durham in many different countries. Between 2008 and 2009, we organised together two conferences on this theme in South Asia, and I have now come here to look into the Southeast Asian experiences. I have been coming to Malaysia again and again for the past 15 years and I have had the privilege of working with some of the country's leading law brains, including the legendary scholar, the late Ahmad bin Mohammad Ibrahim, former Chief Justice Tun Abdul Hamid, and Islamic law specialist Professor Mohammad Hashim Kamali.

At this preliminary session of the conference, I am presenting a very brief overview of the legal framework of religion-state relations in Southeast Asia. To the scholars from Malaysia and other Southeast Asian nations present here, my

* Professor Tahir Mahmood is Chairman of the Institute of Advanced Legal Studies at Amity University, India. This paper features the author's speech as delivered at the conference on Religion, Law and Governance in Southeast Asia's inaugural session. 
presentation would sound very elementary; but it would probably set the ball rolling for discussions in our forthcoming business sessions.

According to a general consensus among geographers, Southeast Asia includes eleven major countries which I am mentioning here in the descending order of their population. With its 230 million-strong citizenry, Indonesia is on the top of this list, and Brunei with its half a million nationals at the bottom. Malaysia, with a population of around 28 million, stands at no. 6 on this list - above it being, apart from Indonesia, the Philippines (92 million), Vietnam (85 million), Thailand (63 million) and Myanmar (50 million) - and below it Cambodia (15 million), Laos (6.5 million), Singapore (5 million) and East Timor (1 million).

Though in terms of headcount, Islam is the largest religion of Southeast Asia, it is the faith of the majority only in three states in the region - of the remaining eight six are dominated by Buddhists and two by Christians. The legal framework of religion-state relations is not uniform either in Southeast Asia as a whole or within any of these three religion-based groups of countries. What follows is a brief overview.

\section{Muslim-Dominated Countries}

With its largest Muslim population on the globe, Indonesia has no legally proclaimed state religion, but the Islamic tenet of monotheism has a place of pride in its Constitution. ${ }^{1}$ Beginning with the words "By the grace of God Almighty", the Constitution declares that the state is built on "belief in the One and Only God". It contains a separate Chapter on Religion which substantially reiterates this prefatory affirmation before assuring that everybody shall have "freedom of worship, each according to his or her own religion or belief", and freedom "to choose and practise the religion of his or her choice". Moreover, a law relating to the administration of justice mandates the judges to act "with full responsibility to Almighty God". ${ }^{2}$ The Indonesian judiciary comprises of secular and Muslim religious courts - the former applying general laws of the country and the latter administering Islamic law to the Muslims in matters of personal status and family relations. While the general laws of the country remain secular, in the Aceh Darussalam territory attempts have been made to bring more aspects of life under Islamic law.

With regard to Malaysia, ${ }^{3}$ the Federal Constitution here declares that "Islam is the religion of the Federation but other religions may be practised in peace and harmony in any part of the Federation." Guaranteeing to all citizens the right to "profess, practise and propagate" religion, and to all communities to manage their religious affairs, establish and maintain institutions for religious or charitable purposes, and acquire and own property in accordance with law - empowering the state however to regulate all these rights in the interest of health or morality. It further says that 
no person will be forced to receive instruction in or take part in any ceremony or act of worship belonging to a religion other than his own, or to pay a tax fully or partly allocated for any other religion.

There are special provisions in the Malaysian Constitution for the state religion and its followers. The King of Malaysia is "Head of the religion of Islam" in the Federal Territories and in the states of Malacca, Penang, Sabah and Sarawak - while everywhere else this position is held by the respective heads of states. The most conspicuous Islamic provision in the Constitution is the one empowering the state to control propagation of other religion among the Muslims, in terms of which laws called Non-Islamic Religions (Control of Propagation among Muslims) Enactments have been locally enacted. ${ }^{4}$ A National Council for Islamic Affairs works under the Constitution at the federal level and has its counterparts in most of the states. Further, the state is authorised to establish or maintain institutions for Islamic religious instruction, or provide active assistance for this purpose. Of course other religious groups also are assured the right to establish and maintain institutions for the education of children in religion and the state cannot discriminate against such institutions in respect of financial support and administrative regulation.

The judiciary in Malaysia consists of general courts and Muslim religious courts, both having civil and criminal jurisdiction. A Syariah Courts (Criminal Jurisdiction) Act was enacted by the Federal Government in 1965 and an Islamic Family Law Reform Act in 1984. Parallel civil laws are in force in almost all the states, and parallel penal laws in six of them. ${ }^{5}$ In the states of Kelantan and Terengganu there have been moves to bring more aspects of life under the traditional Islamic law. On the other hand, national-level Malaysian rulers of the recent past propounded the liberal concept of Islam Hadhari (Civilisational Islam) focusing on the civilisational aspects of the Islamic faith.

In the neighbouring Brunei - the smallest but richest state of Southeast Asiathe Constitution proclaims Islam according to its Shāfi $\overline{1}$ interpretation to be the state religion. ${ }^{6}$ Like in Malaysia, in Brunei, too, the Head of the State is head of the Islamic religion, and there are Islamic councils and courts regulated by the Religious Councils, Kathis Courts and State Customs Act of 1955.

\section{Buddhist-Dominated Countries}

In four of the six Buddhist-dominated countries of Southeast Asia the Constitutions accord to Buddhism the status of state religion or an otherwise privileged tradition.

In Thailand, ${ }^{7}$ the Constitution declares the King to be a "Buddhist and Upholder of Religions" (note the plural!) and mandates the state "to patronise and protect Buddhism as the religion observed by most Thais for a long period of time". A Constitutional body called the Sangha Supreme Council controls Buddhist religious 
affairs, currently as per the new Sangha Act of 1962. The Constitution, however, directs the state also to "patronise and protect other religions, promote good understanding and harmony among followers of all religions, and encourage the application of religious principles to create virtue and develop the quality of life". In terms of this provision a Religious Organisations Act was enacted in 1969 and the Administration of Islamic Organisation Act in 1997 for the Muslim minority which provides for the appointment of an official traditionally known to the Muslims by the Arabic expression shaykh al-isläm and within the Thai administrative framework as chularajmontri, by the King and regulates of statutory Central and Provincial Islamic Committees. The Thai Constitution also prohibits religion-based discrimination by the state and guarantees everybody "full liberty to profess a religion, a religious denomination or creed, and observe religious precepts or commandments or exercise a form of worship in accordance with his belief; provided that it is not contrary to his civic duties, public order or good morals". Islamic law and sharì ah courts operative in the Muslim-dominated regions have state sanction.

In Cambodia, ${ }^{8}$ where religion is included in the triple 'motto of the State', along with Nation and King, the Constitution declares Buddhism to be the state religion, mandating the state to "disseminate and develop Pali" schools and Buddhist institutions". Freedom of religious belief and worship is however guaranteed "on the condition that such freedom does not affect other religious beliefs or violate public order and security", and religion-based discrimination is prohibited. A Ministry of Cults and Religious Affairs regulates religious affairs of all communities.

In Myanmar, ${ }^{10}$ without formally proclaiming Buddhism to be the state religion, the Constitution recognises its "special position as the faith professed by the great majority of the citizens of the State" - adding that the state also recognises Christianity, Islam, Hinduism and Animism. Promising possible state assistance to all recognised religions, it assures non-discrimination on religious grounds and - subject to public order, morality, health and other provisions of the Constitution - guarantees freedom of conscience right to freely profess and practise religion. Religious communities are given the right to develop their respective religions and customs subject to "laws enacted for State security, prevalence of law and order, community peace and tranquillity or public order and morality" and "without prejudice to relations between one national race and another, or among national races and to other faiths". The Myanmar Constitution borrows from its Indian counterpart the provision that the right to religious freedom does not preclude the state from enacting laws to regulate "any economic, financial, political or other secular activities that may be associated with religious practice" or for "social welfare and reform". It also specifically forbids "abuse of religion for political purposes" and acts "intended or likely to provoke feelings of hatred, enmity or discord between racial or religious communities or sects is contrary". Religion- 
based family laws inherited from the British colonial era remain in force with some later reforms.

In $\operatorname{Laos}^{11}$ the Constitution says that the "State respects and protects all lawful activities of the Buddhists and of followers of other religions, and mobilises and encourages the Buddhist monks, and novices and priests of other faiths, to participate in those activities which are beneficial to the country and its people" - adding that "all acts of fomenting division among religions and among the people are prohibited". At the same time it recognises "right and freedom to believe or not to believe in religions" and assures equality of all citizens irrespective of their faith and ethnicity. A Decree on Management and Protection of Religious Activities issued in 2002 allows religious communities to manage their affairs under state control. Although all religions are recognised, the dominant Buddhist faith reportedly enjoys relatively more freedom under its provisions.

In Singapore ${ }^{12}$ there is no state religion and the Constitution guarantees equality and non-discrimination on religious grounds. Individuals' right to profess, practise and propagate religion is protected; and so is that of religious groups to manage their religious affairs, establish and maintain institutions for religious or charitable purposes, and acquire and own property in accordance with law. In respect of religious education and taxation the Singapore Constitution dittoes parallel provisions of the Malaysian Constitution noted above. Further, there is a Presidential Council for Minority Rights acting under the Constitution, and a Presidential Council for Religious Harmony working under the Maintenance of Religious Harmony Act 1992. The Constitution mandates the Legislature to make provision for regulating Muslim religious affairs and for constituting a Council to advise the President in matters relating to the Muslim religion. An Administration of Muslim Law Act was accordingly enacted in 1966 governing the Singapore Islamic Council and regulating application of Islamic law to the Muslims and working of Islamic religious courts.

Vietnam, too, has no state religion and the national Constitution recognises legal equality of all citizens. ${ }^{13}$ Declaring that all religions are equal before the law, it adds that every citizen has a right to "practise or not practise any religion" and that no one can use religious freedom to "violate state laws and policies". Speaking explicitly of a "multi-ethnic Vietnamese civilisation", the Constitution also prohibits ethnic discrimination. Of late, a liberal regime of religious freedom has been established under the Belief and Religion Ordinance of 2004, followed by its Implementation Decree of 2005.

\section{Christian-Dominated Countries}

In the Philippines, ${ }^{14}$ the Constitution is based on the United States model and declares that the separation of Church and State shall be inviolable; no law shall 
be made respecting an establishment of religion or prohibiting free exercise thereof; free exercise and enjoyment of religious profession and worship without discrimination or preference shall for ever be allowed; and no religious test shall be required for the exercise of civil or political rights. In a leading case, the Supreme Court of Philippines, interpreting the Constitution, has propounded what it called "doctrine of benevolent neutrality-accommodation" is virtually laying down that - unlike in the US where legislative exemptions of religion had to be upheld by the Supreme Court as constituting permissive accommodations - in the Philippines such exemptions for religion are mandatory. Islamic law and sharì $a h$ courts remain operative in the constitutionally recognised Muslim autonomous regions. Muslim family law was codified in 1977 and a semi-official mufti is authorised to issue religio-legal edicts.

In East Timor, ${ }^{15}$ although acknowledging that the Catholic Church "has always been able to take on the suffering of all the People with dignity, placing itself on their side in the defence of their most fundamental rights", the Constitution declares that there shall be no official religion and the state shall "respect different religious denominations" and promote "cooperation with different religious denominations that contribute to the well-being of the people of East Timor". Individuals are assured freedom of conscience, religion, worship, non-discrimination on religious grounds and non-persecution for being a "conscientious objector". Religious denominations - "separated from the State" - have the freedom to "organise and exercise their own activities in due observance of the Constitution and the law", possess and acquire assets for the achievement of their objectives, and teach religion "in the framework of respective religious denominations". Customary laws are to be recognised by the state subject to the Constitution and state legislation, but "women and men shall have the same rights and duties in all areas of political, economic, social, cultural and family life".

\section{Concluding Remarks}

The wide diversity of religion-state relations in Southeast Asia is indeed fascinating. I have laid here only the basic legal framework relating to the theme of this conference operative in various countries of this region. "Easier said than done", they say, and in respect of religious rights of the people the practice is certainly not as rosy as the theory anywhere in the world. Southeast Asia is no exception and there certainly are problems of multifarious nature and different dimensions in almost all countries of the region - like in most other countries of the world. I have deliberately not touched upon them as we will have ample opportunity to talk of them in our forthcoming business sessions. 


\section{Notes}

1. Constitution of Indonesia 1945, Arts 28-29.

2. Law no. 14 of 1970.

3. Constitution of Malaysia 1960, Arts 3, 11-13.

4. Johor, Kedah, Kelantan, Melaka, Negeri Sembilan, Pahang, Perak, Selangor, and Terengganu.

5. Pahang, Perak, Melaka, Sabah, Terengganu and Kelantan.

6. Constitution of Brunei Darussalam 1959, Art. 3.

7. Constitution of Thailand, 2007, Arts 5, 9, 37 and 79.

8. Constitution of Cambodia 1993, Arts 43, 68.

9. Pali is the language of many of the earliest extant Buddhist scriptures, as collected in the Pali Canon or Tipitaka, and as the liturgical language of Theravada Buddhism.

10. Constitution of Myanmar, Arts 4, 10, 16-22, cf. Constitution of India 1950, Art. 25.

11. Constitution of Laos 1991, Arts 9, 22, 30, 43.

12. Constitution of Singapore, Arts 12, 15-16, 68-92 and 153.

13. Constitution of Vietnam 1992, Arts 5, 30, 52 and 70.

14. Constitution of Philippines, Art. III Section 5; Art. II Section 6.

15. Constitution of East Timor, Preamble Arts 12, 17. 